$\mathrm{S}$

581.7

F2VMM 2005

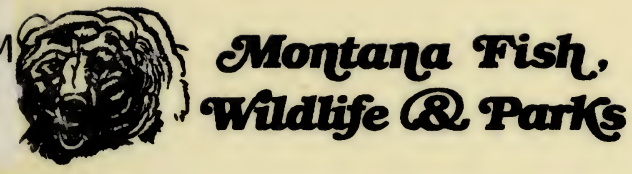

\title{
VEGETATION MONITORING MANUAL
}

\author{
Bob Harrington \\ MFWP Vegetation Specialist \\ 2005
}

Federal Aid in Wildlife Restoration Project W-154-R 
Montana State Library

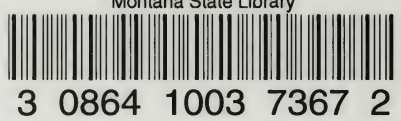




\section{Foreword}

This manual describes Montana Fish Wildlife \& Parks (FWP) vegetation monitoring techniques. Techniques and methodologies described in this manual are designed to quantify vegetation characteristics (plant cover by primary species, canopy cover of shrub species and plant density) and current soil surface conditions. Methods for photo plots and photo points are also described.

In development of this manual the author recognizes the need to assess changes in both vegetation and the soil surface. Information regarding these parameters provides insight of temporal change. The methodologies used to assess changes in vegetation and soil surface are time tested and allow for repeat measurements by different investigators.

\section{STATE DOCUMENTS COLLECTION}

\section{APR 282006}

MONTANA 8TATE LIBRARY. 1515 E. 6th AVE. HELENA. MONTANA 59620 


\section{Table of Contents}

1. Introduction..................................

2. Methods....................................2-15

3. Literature Cited..............................16

4. Appendices.............................17-21

\section{List of Tables}

1. Daubenmire Cover Classes....................7

2. Line Intercept Data Example..................8

\section{List of Figures}

1. Example of a Photo Point......................2

2. Example of a Photo Point........................ 3

3. Level 2 Transect layout......................6

4. Example of a Photo Point.................... 9

5. Example of Photo Plot........................ 10 


\section{Introduction}

Areas that are not cultivated, barren deserts, covered by ice, solid rock or concrete can be classified as rangelands (Holecheck et al. 1989). Hence, natural grasslands, forests and deserts are rangeland. Dyksterhuis (1955), Hedrick (1966), Society for Range Management (1974), and Stoddart et al. (1975) offer varying definitions of rangeland but all share the basis that rangelands are uncultivated and able to provide habitat for domestic and wild animals (Holecheck et al. 1989). 1 define rangeland as uncultivated land that will furnish the requirements of life for native and non-native grazing and browsing animals while also providing some life requirements for non-grazing and non-browsing animals.

Montana Fish Wildlife \& Parks (MFWP) owns several Wildlife Management Areas (WMAs) and Conservation Easements. MFWP recognizes the need to monitor the vegetation on these lands to assess management activities (e.g managed grazing). The purpose of this manual is to clearly describe techniques and procedures used to monitor rangeland vegetation and soil surfaces. MFWP uses three levels of vegetation monitoring; comprehensive, moderate and photographic. Comprehensive vegetation monitoring includes a vegetation map based on a comprehensive floristic survey, a statistically determined number of plant/soil permanent transects established in a vegetation type of interest, collection and documentation of all plant species encountered, and establishment of permanent photo plots and photo points. A moderate level of vegetation monitoring involves installation of a few transects, photo plots, and photo points in an area of interest (perhaps a small area that will show change over a short period of time). To develop a photographic level of vegetation monitoring, MFWP establishes several photo points in an area of interest such as along a permanent route. Methodologies include; photo points, photo plots, line intercept transects, belt transects, cover transects (Daubenmire 1958), and soil surface assessment transects.

Rangeland monitoring determines what is occurring to the resource over time. Land managers should monitor to assess impacts of the current management practices on the rangeland. It is necessary that both vegetation and soil attributes be assessed when monitoring rangeland sites in order to describe current status and to predict trends (Tongway et al. 1995). This involves observation, gathering data, and keeping accurate records over time to detect and quantify soil and vegetation changes. Information from such monitoring assists with the day-to-day and long-term management of rangelands.

This manual defines MFWP office and field procedures for vegetation monitoring on WMAs and Conservation Easements. The aim of vegetation monitoring is to furnish objective information and data on changes in vegetation and soil surface characteristics to (1) the WMA manager and area biologist, other Department personnel and (2) other State and, (3) Federal agencies as needed. The objective of vegetation monitoring is to quantify changes in rangeland vegetation and soil surface characteristics and to interpret these changes in terms of causal associations and implications for future management. 


\section{LEVEL 1}

\section{Methods}

\section{Photo Point:}

This method is a qualitative method of vegetation monitoring that can be performed by anyone. The strengths of repeated photographs in monitoring vegetation changes are: a complete inventory of the site is captured in the picture, rates of vegetation change and occurrences associated with that change are documented, and the field work can be accomplished rapidly and easily. In addition, photo points (Figures $1 \& 2$ ) provide a unique record in that they portray changes on a large scale and this information can be provided to audiences of different backgrounds and interests.

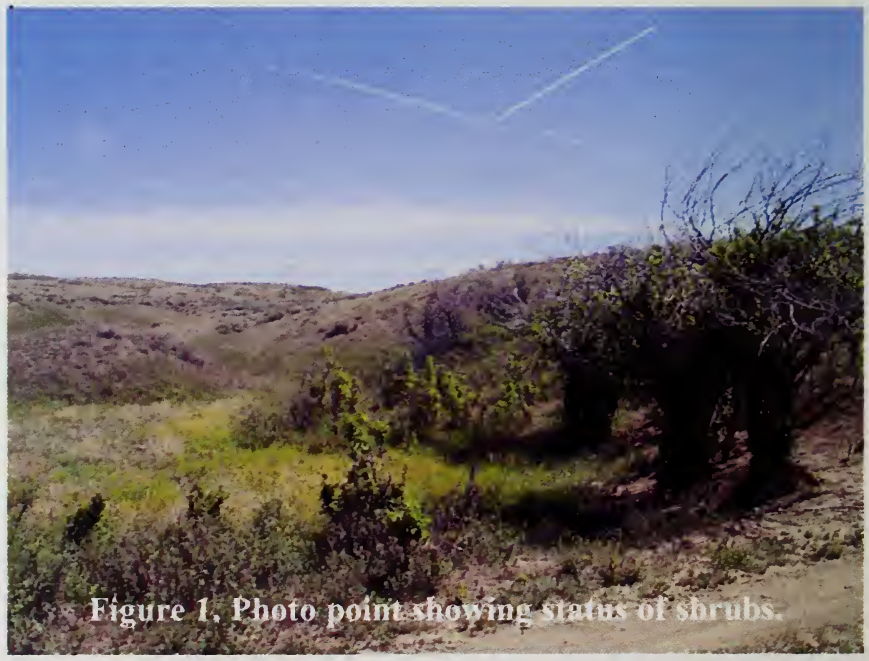

The weaknesses of photo points are: observable qualitative changes in botanical composition are limited to only obvious species changes. At present, MFWP uses a digital camera for all vegetation monitoring. Photographs are taken and stored in an uncompressed TIFF format to ensure high quality. 
Figure 2. Photo point showing sagebrush distribution.

First, a determination of what vegetation types are to be monitored must be made. A tour through the property, visiting with landowners, area biologists, and other people familiar with the property can be of assistance. A photo point route is established on existing roads or two-track trails focusing on specific vegetation type(s). While driving through the property, establish as many photo points as are necessary to represent the vegetation types of interest. Photo points should be established in uplands and riparian zones (where change can take place rapidly) and in disturbed areas (i.e. past high livestock concentration areas) that may respond to a management strategy change (i.e. season-long to rest rotation grazing). A photo point field form (Appendix 3) is completed on site and includes the following information: (1) property name and county, (2) photo point number or name, (3) name of photographer, (4) date of photograph, (5) date photo point was established, (6) time of day, (7) magnetic declination, (8) GPS coordinates, (9) a description of the area including conspicuous landmarks and (10) general comments and notations describing obvious vegetation, soil, and growing conditions. A steel fence post is recommended to mark the point but a GPS reading and previous photos may be adequate to relocate the point. 
Once the photo point route is established, the point locations are entered into a GIS database. Photographs are then downloaded into a PC and stored in uncompressed TIFF format for later analysis. Photo points are then re-photographed at an interval determined on a case-by-case basis. Some photo point routes will be re-photographed every year (ideally at the same time of year) whereas some will be re-photographed at longer intervals.

\section{LEVEL 2}

\section{Moderate Vegetation Monitoring:}

The second level of MFWP's vegetation monitoring involves establishing a few long-term vegetation monitoring sites in a representative vegetation type of interest. Canopy cover (Daubenmire 1958), line intercept (Canfield 1941), belt transects, soil surface assessment (Tongway 1994), photo points, photo plots, and browse evaluation (Kiegley and Frisina 1998) are the methodologies used at this level. The Daubenmire (1958) method is used to measure the canopy coverage of herbaceous species. The line intercept technique is used to ascertain aerial cover of shrub species, and belt transects are used to determine plant density of a target species. Soil surface assessment transects are used to monitor the soil surface over time. Soil surface monitoring appraises the soil's ability to absorb and store precipitation, hold and cycle nutrients, provide adequate sites for seed germination and establishment of plants, and to combat erosion. Photo points are used to supply a photographic record to monitor vegetation, but do not generate specific data quantifying cover and density. Photo plots are also photographic records of vegetation but on a small scale. Photo plots are photographs of specific plots or quadrats that are repeated over time. 


\section{Site Selection:}

Use available maps, aerial photographs, baseline inventories and other information, to identify habitat and vegetation types of interest that can be monitored on a three to five year cycle. Choose potential site locations in each type and select more sites than required, as some of the sites will be found unsuitable in the field. When possible, evenly distribute sites over the area within the habitat/vegetation types, but give priority to locating sites within the largest type or areas of special concern. Avoid locating sites within isolated or small areas that may be preferentially grazed or browsed. Locate sites where management concerns will be addressed. Sometimes this will be in the center of a habitat/vegetation type whereas other times this will be on the margins or ecotones to quantify advancement or decline. Attempt to locate sites away from watering points, fence lines, or other known animal concentration areas. If possible review the potential site with appropriate personnel to identify any "unknowns" that may adversely impact the site. Execute an ocular reconnaissance on all the habitat/vegetation types to identify potential areas of specific concern within each type. Locate sites so that they will not be unnaturally affected by roads, infrastructure, watering points, and other influential factors, but not within $150 \mathrm{~m}$ of a fence line. For ease of location, sites should be within $300 \mathrm{~m}$ of a trail or two-track road. Establish the centerline of the site up slope, perpendicular to the contour.

\section{Transect Layout:}

Typically, at this level of vegetation monitoring, the monitoring site is comprised of three $30 \mathrm{~m}$ parallel transects orientated uphill. Once an acceptable location for a site has been selected, the installation of transects follows. Upon site completion, there will be 7 permanent markers on the site. The permanent markers are $1 \mathrm{~m}$ pieces of rebar with a yellow cap used to mark the start and end of each transect. 
Angle iron fence posts are used to mark the bottom of the site and are located approximately $5 \mathrm{~m}$ below transect 2 . Installation of the fence post away from the transect eliminates animal curiosity which may result in rubbing, increased grazing, browsing, and trampling.

The diagram (Fig. 3) illustrates transect layout, site orientation, and other details needed to establish the site. The diagram also depicts Daubenmire cover transects and belt transects. Transects are always established perpendicular to the contour of the site. Transects 1 and 3 are located $6.5 \mathrm{~m}$ parallel on each side of transect 2 and marked in the same fashion. This will create 3 parallel transects at $6.5 \mathrm{~m}$ intervals.

\section{Vogetation Monitoring Site \\ Diagram}

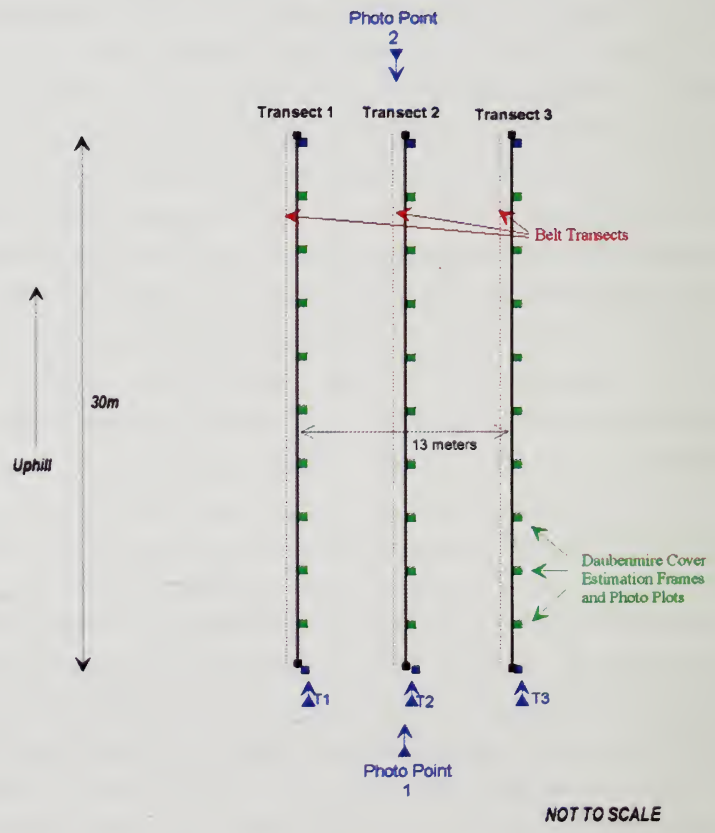

Figure 3. Vegetation Monitoring Site Diagram

(Blue $=$ Photo Points) 


\section{Canopy Cover Method:}

Daubenmire (1958) suggested a scale of a $0.1-\mathrm{m}^{2}$ quadrat (20 X $50 \mathrm{~cm}$. inside dimensions) to be satisfactory for estimating herbaceous cover. The quadrat is laid along the right side of the tape measure every $3 \mathrm{~m}$ starting at the $3 \mathrm{~m}$ location and ending at the $30 \mathrm{~m}$ point of the transect. This allows for 10 quadrats per transect to be measured. The quadrat is placed on the ground with the upper left corner of the quadrat at the $3 \mathrm{~m}$ point. Plant cover is estimated by species. Litter and bare ground are also estimated as separate categories. Estimations are made and recorded according to cover classes defined by Daubenmire (Table 1).

Table 1. Cover classes rated according to percentage of ground surface covered by vegetation (from Daubenmire 1958)

\begin{tabular}{|c|c|c|}
\hline Cover Class & \% Cover Range & Midpoint \\
\hline 1 & $0-5$ & 2.5 \\
\hline 2 & $5-25$ & 15.0 \\
\hline 3 & $25-50$ & 37.5 \\
\hline 4 & $50-75$ & 62.5 \\
\hline 5 & $75-95$ & 85.0 \\
\hline 6 & $95-100$ & 97.5 \\
\hline
\end{tabular}

\section{Line Intercept Method:}

Canfield (1941) introduced the line intercept method for sampling rangeland vegetation. The method includes horizontal and linear measurements of plant intercepts along a course of a line (tape measure). The primary purpose is to measure foliar and basal cover and plant species composition of graminoids, forbs, shrubs and trees. This methodology is appropriate where it is easy to lay out straight lines in vegetation generally less than $2 \mathrm{~m}$ tall and where the boundaries of plant growth are relatively easy to determine. It is not an easy method for estimating cover on single-stemmed species, dense stands of grass, or litter. 
The line intercept method is well suited to estimate cover of shrub species. Accuracy decreases when it is difficult to set up a straight line using a stretched tape and it is difficult to determine where the margin of the plants' canopy is. Multiple transects, as opposed to a single transect, are preferred to guarantee adequate sampling of the site. Data should be recorded to the nearest centimeter using a $3 \mathrm{~cm}$ gap criteria (i.e., a gap larger than $3 \mathrm{~cm}$ in the canopy).

The method is applied using a tape measure as the line for the transect. The intercept of each target species is measured from the tape and recorded. The total amount of intercept is tallied for each transect and cover and botanical composition are computed. Any length of transect can be used, but sites will typically use three parallel $30-\mathrm{m}$ lines. Computations necessary to determine plant cover and botanical composition for a hypothetical plot of three $30-\mathrm{m}$ transects are illustrated in Table 2.

Table 2: Hypothetical Data Illustrating Line Intercept Computations:

\begin{tabular}{|c|c|c|}
\hline Species & Intercept $(\mathrm{cm})$ & $\%$ Cover \\
\hline big sagebrush & 900 & 10.0 \\
\hline serviceberry & 650 & 7.2 \\
\hline wild rose & 420 & 4.6 \\
\hline Total & 1970 & 21.8 \\
\hline \multicolumn{2}{|c|}{ (three $30 \mathrm{~m}$ transects $=9000 \mathrm{~cm}$ ) } \\
\hline \multicolumn{2}{|c}{} \\
\hline
\end{tabular}

\section{Belt Transect Method:}

A belt transect is a rectangular shaped quadrat used to determine the number of a species in a known area, or plant density. Plant density data can be focused on a plant species or by a plant species age class distribution. Cooper (1959) and Duvall and Blair (1963) define density as the number of plants per unit area.

When plant density is of interest, the investigator can simply use the existing 3 parallel transects. A second tape measure is placed $1 \mathrm{~m}$ to the left of each transect creating a $1 \times 30 \mathrm{~m}$ belt. The investigator records all key species of interest that are rooted within the belt. 
If age class distribution is of interest the investigator separately records the key species by seedlings, juvenile, and mature plants. A $15 \mathrm{~cm}$ average crown (from 4 measurements at right angles to each other) criteria, $[<15 \mathrm{~cm}=$ juvenile (Wambolt and Sherwood 1999)], is used to separate big sagebrush juveniles and mature plants.

\section{Photo points:}

Five permanent photo points are established at each long-term habitat-monitoring site. The strengths of repeated photographs in monitoring vegetation changes are (1) a complete inventory of the site is captured, (2) rates of vegetation change and occurrences associated with that change are documented, and (3) the field work can be accomplished rapidly and easily. The weakness of photo points is observable changes in botanical composition are limited to obvious species changes. The photo points are located at five positions in the site. Photo point 1 (Fig. 4) is located at the base of the site looking up and photo point 2 is located at the top of the site looking down. Photo points $3,4 \& 5$ are located at the base of transects T1, T2 \& T3 looking straight up the transect (Fig. 3).

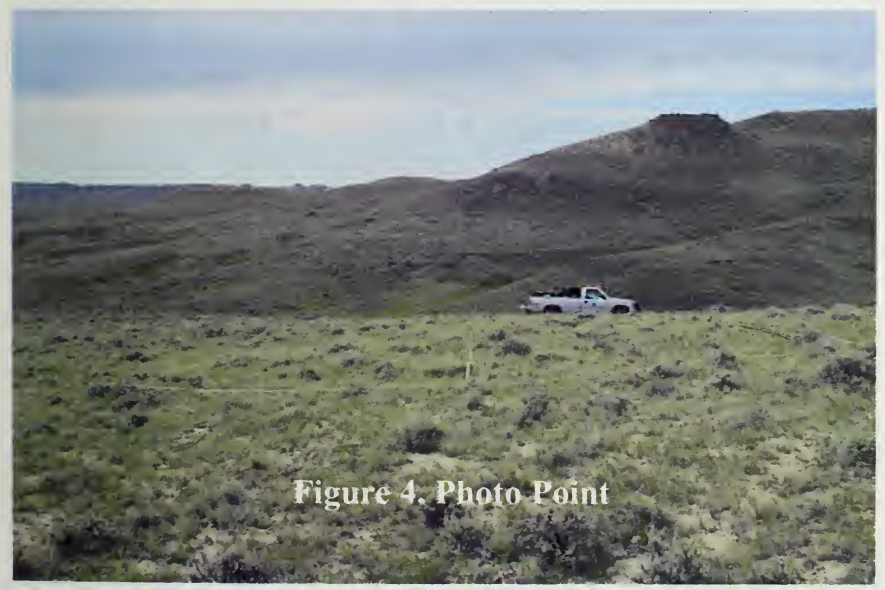




\section{Photo plots:}

Photo plots are photographs of the Daubenmire cover frames of each transect (Fig. 5).

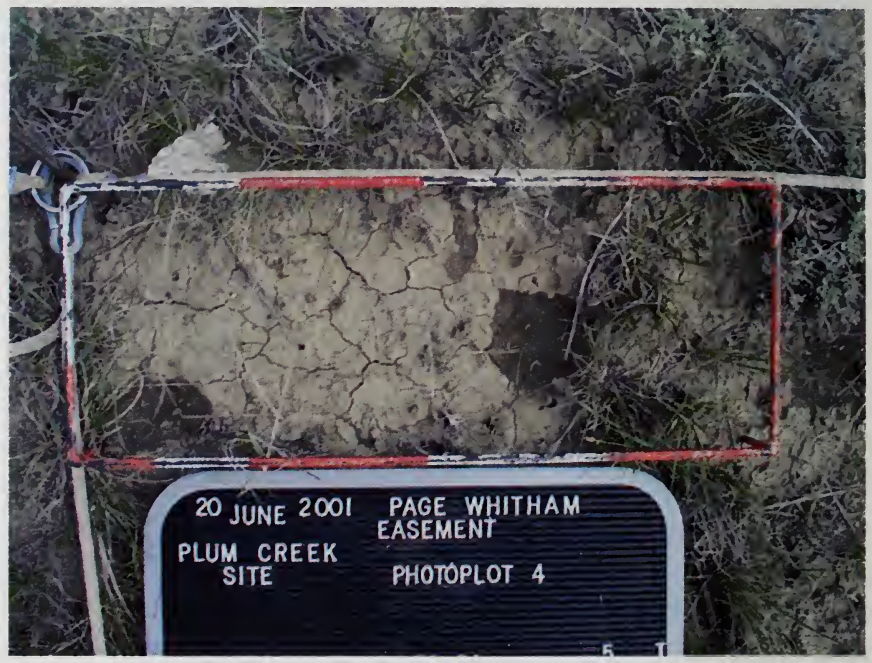

Figure 5. Photo Plot

The photo is taken approximately 2 to 3 feet above the plot looking straight down and is repeated over time. Exact repetition is guaranteed as the start and end of each transect is marked with a 4' rebar driven into the ground then capped with a yellow cap. In addition, the start and end of each transect is marked with a pile of rocks.

\section{Browse Evaluation by Analysis of Growth Form:}

Browse evaluation by analysis of growth form is a plant-architecture survey developed by Keigley and Frisina (1998). The survey can determine if trees are growing to a stature typical for their species. This reflects the degree of historical ungulate use. This method measures the effect of browsing on plant architecture. There are two levels of this survey method: reconnaissance-level and comprehensive level. 
A reconnaissance-level survey provides a qualitative browsing history, determines the current level of browsing (light to moderate vs. intense), and possibly determines short-term trends. A comprehensive-level survey comprises a reconnaissance-level survey, determines the net annual growth rate of the target species and reconstructs the long-term year-by-year browsing history of the site. Complete instructions for this method can be found in the FWP manual Browse Evaluation by Analysis of Growth Form (Keigly \& Frisina 1998).

\section{Soil Surface Assessment Method:}

Soil surface assessment observations are used to monitor the soil surface over time. Soil surface monitoring appraises the ability of the soil to absorb and store precipitation, hold and cycle nutrient elements, provide adequate sites for seed germination and establishment of plants, and to combat erosion (Tongway 1994). Soil surface attributes are measured while measuring and recording data on Daubenmire transects.

The following techniques were adapted and modified based on (Tongway et a1.1995) manuals developed for Australian rangeland. There are fundamental differences between Australian rangeland and rangelands of the Western United States. However, the concepts of these manuals have direct application to rangelands of the Western United States. A fundamental theory of this technique is that soil is a habitat that interacts with climate and terrain type resulting in the vegetation type (Tongway 1994). Tongway suggests that the climate and the soil/terrain type can be thought of as the "environmental envelope." Changes to soil quality by some disturbance or degradation process may alter the environmental envelope for some species to the magnitude that those species cannot persist (e.g. loss of perennial grass or shrubs).

This is a quadrat-based procedure that quantifies eleven soil surface attributes to classes. MFWP uses six soil surface attributes; soil cover (rain), soil cover (flow), crust brokenness, cryptogam cover, erosion features, and soil microtopography. Refer to Appendix 1 for the soil surface attribute scoring tables. 


\section{Soil cover (rain)}

The objective of this measurement is to assess the degree to which the soil surface cover resists rain splash erosion. The measurement is percent cover of perennial grasses, forbs and shrubs to a height of $0.5 \mathrm{~m}$, rocks, sticks, or any other longlived objects that will intercept raindrops and guard the soil from rain splash erosion. "Gravity drops" falling from a height greater than $0.5 \mathrm{~m}$ have a high erodibility so foliage at $0.5 \mathrm{~m}$ and greater are ignored in this section. Litter is assessed separately. Soil with more protection has a lower potential for future erosion.

\section{Soil cover (flow)}

The objective of this measurement is to assess the cover of objects that obstruct or divert overland flow. These are longlived objects that are 1-2 cm above the soil surface (e.g. plant bases, sticks, rocks, wood, etc.), which hinder and divert overland water flow. They slow down the overall flow-rate and increase the depth of flow, thereby reducing soil and organic matter transportation. Many small features are more effective than a few large ones. The key question is "To what extent will the soil surface objects reduce the erosive power of overland flow?"

\section{Crust broken-ness}

This measurement appraises to what degree surface crust materials are broken or loosely attached and available for erosion. In this context, crusts consist of thin layers of finetextured soil overlying the soil proper. Smooth, unbroken crusts give up less material than crusts that are broken into fragments and are mechanically fragile. Soils without natural crusts such as self-mulching surfaces and loose sands and sandy banks are excluded. 


\section{Cryptogam cover}

This measurement assesses the cover of cryptogams (algae, fungi, cyanobacteria, lichens, mosses, and liverworts). These plants can only exist on stable, non-shifting surfaces with access to light. They are often pioneer species or early colonizers of disturbed soil and are positive indicators of surface stability. Cryptogams are useful in assessing soil surface stability and are assessed as percent cover. Soil crusts with cryptogams are typically flexible and resist disturbance. By removing a cryptogam-crusted soil 'plate', fine roots or hyphae can be observed across the break, which add greatly to the soil crust robustness. Research has shown that the soil beneath cryptogam crust usually indicates higher levels of nitrogen and carbon in the immediate soil surface, suggesting that cryptogams are involved with establishment of healthy nutrient profiles.

\section{Erosion features}

These are visible signs of active, current loss of soil material from the quadrat. These features are used to assess how the surface soil responds to erosive forces of wind and water. The feature may be a channel or rill, a terrace, plant pedestaling, or sheet erosion. Care must be taken not to confuse soil accumulated around grass bases as signs of pedestaling. Accumulation-hummocks have unconsolidated soil, and if sectioned with a knife, layers of deposition are revealed. Pedestals are much more coherent and fine-textured, having no signs of layering. These features are small, as are the areas they occupy, but are important because they flag a potential problem. On occasion, active erosion scars may improve. This is evidenced by smooth, rounded edges and pioneering by cryptogam.

\section{Soil microtopography}

This assessment quantifies the soil surface features which detain water on the quadrat between the time the surface becomes wet (ponded) and the time water actually runs off the quadrat area (runoff). 
Soils which can absorb and store water have a higher biological activity than those where water runs off or is evaporated. Soil microtopography is comprised of a series of unconnected micro depressions, or bowl-shaped structures, several millimeters deep and 1 to $5 \mathrm{~cm}$ across. A second function for microtopographic features is to provide safe germination sites because of their accumulation, retention, and protection characteristics. Macro structures larger than the sampling frame are excluded. Livestock foot impressions are not included as their persistence is unknown and not necessarily related to the processes that produce shallow depressions naturally. The assessment estimates the volume of detention based on the depth criteria in the table.

\section{LEVEL 3}

\section{Comprehensive Vegetation Monitoring:}

The third level of vegetation monitoring is a comprehensive approach involving vegetation mapping (floristic survey), plant collection, and a statistically based number of permanent vegetation transects. The first step at this level is creation of an ArcView project (APR) with the following themes; hydrology, roads, property boundaries, PLSS (Public Land Survey System), watershed basin, appropriate Mr. SIDS (digital orthophotos) and the GAP Silc2 vegetation data. All themes should be in state plane projection. Once the APR is built, a series of layouts are created showing existing vegetation (GAP) and digital orthophotos with property boundaries, PLSS, roads, and hydrology. The layouts serve as references when in the field and the orthophoto layouts are used for actual vegetation mapping.

With the reference ArcView layouts in hand, the investigator walks each section of the property and records boundaries of vegetation types on the orthophoto layout. While doing the mapping, a comprehensive plant list is also kept and desired plant specimens are collected for the MFWP herbarium. 
Once the mapping is complete, a determination is made of what vegetation type to monitor. Typically, this is the dominant type found on the site or one of particular interest (i.e. sagebrush/ grassland). Vegetation transects should be stratified over a vegetation type. The vegetation type may extend for several miles or may be smaller, so three initial transect are installed using the same techniques as in level 2. The distance between each transect is site dependant but should be several hundreds yards apart. Once data are collected from the three transects, an adequacy of sample formula is used to determine the number of transects necessary to statistically detect differences/changes.

$$
\text { The formula is: } \mathrm{n}=\left(\frac{S T}{L \bar{X}}\right)^{2}
$$

$\mathrm{L}=$ the $\%$ within the mean you want to sample $-10 \%$ is very common and generally used

$\overline{\mathrm{X}}$ is the mean of the parameter measured

$\mathrm{T}=$ from a table of $\mathrm{t}$ values, typically 1.96 is used, that is $\mathrm{t} @$ $p=0.25$ with $\infty$ degrees of freedom.

$\mathrm{S}=$ standard deviation

The investigator has some flexibility with this formula. L can be adjusted to $20 \%$ if desired, which will reduce the number of transects necessary while still explaining $80 \%$ of the variation. The formula will always say additional transects are needed so some judgment in the field is required to be realistic.

\section{Data Analysis:}

Data are entered, stored and analyzed in a Microsoft Access program that resides on the Departments' plant specialist's computer. Summary reports are generated as needed. The locations of all transect and photo points are entered into a GIS for spatial analysis and all photographs are transferred and stored on the computer mentioned above. 


\section{Literature Cited}

Canfield, R.H. 1941. Application of the line interception method in sampling range vegetation. J. Forestry 39:388-384

Cooper, C.F. 1959. Cover vs. density. J.Range Manage. 12:215.

Daubenmire, R.F. 1958. A canopy-coverage method of vegetational analysis. Northwest Sci. 53:43-64.

Duvall, V.L. and R.M. Blair. 1963. Terminology and definitions. In Range Research Methods. For. Service. U.S.D.A. Misc. Pub. 940:8-11.

Dyksterhuis, E.J. 1955. What is range management?

J. Range Manage. 8:193-196.

Hedrick, D.W. 1966. What is range management?

J. Range Manage. 19:111.

Holecheck, J.L., R.D. Pieper and C.H. Herbal. 1989. Range Management Principles and Practices, Prentice-Hall, Inc.

Keigley, R.B. and M.R. Frisina. 1998. Browse Evaluation By Analysis Of Growth Form. First Edition 1998 Montana Fish Wildlife and Parks.

Society For Range Management. 1974. A Glossary of Terms Used in Range Management, 2nd Edition. Society for Range Management, Denver, Colo.

Stoddart, L.A., A.D. Smith and T.W. Box. 1975. Range Management, 3rd Edition. McGraw-Hill Book Company, New York.

Tongway, D. 1994. Rangeland Soil Condition Assessment Manual. CSIRO, Australia

Tongway, D. and N. Hindley. 1995. Assessment of Soil Condition of Tropical Grasslands. CSIRO, Australia.

Wambolt, C. L. and H. W. Sherwood. 1999. Sagebrush response to ungulate browsing in Yellowstone. J. Range Mgt. 52: $363-369$ 


\section{Appendix 1}

\section{Daubenmire \& Soil Surface Data}

\begin{tabular}{|l|}
\hline Date: $\quad$ Name of Investigator: \\
\hline Name of Location: \\
Transect Number \& GPS Coordinates (UTMs): \\
\hline
\end{tabular}

Transect Orientation (direction transect is read \& what side of tape measure frames were placed):

Slope:

Aspect:

Habitat Type:

Dominant Plant Species:

General Comments (purpose of measurements, growing conditions, weeds, erosion, other disturbances, grazing level, etc.): 
Frames

(cover classes: $1=0-5,2=5-25,3=25-50,4=50-75,5=75-95,6=95-100$ )

\begin{tabular}{|c|c|c|c|c|c|c|c|c|c|c|}
\hline $\begin{array}{l}\text { Grass spp. } \\
1 .\end{array}$ & 1 & 2 & 3 & 4 & 5 & 6 & 7 & 8 & 9 & 10 \\
\hline 2. & & & & & & & & & & \\
\hline 3. & & & & & & & & & & \\
\hline 4. & & & & & & & & & & \\
\hline Other grasses & & & & & & & & & & \\
\hline Forb spp. & & & & & & & & & & \\
\hline 1. & & & & & & & & & & \\
\hline 2. & & & & & & & & & & \\
\hline 3. & & & & & & & & & & \\
\hline 4. & & & & & & & & & & \\
\hline 5. & & & & & & & & & & \\
\hline 6. & & & & & & & & & & \\
\hline 7. & & & & & & & & & & \\
\hline 8. & & & & & & & & & & \\
\hline 9. & & & & & & & & & & \\
\hline 10. & & & & & & & & & & \\
\hline 11. & & & & & & & & & & \\
\hline 12. & & & & & & & & & & \\
\hline Bare ground & & & & & & & & & & \\
\hline Litter & & & & & & & & & & \\
\hline $\begin{array}{l}\text { Soil Surface Assessment } \\
\text { (c page } 2 \text { for scoring tables) }\end{array}$ & & & & & & & & & & \\
\hline Soil Cover (rain) & & & & & & & & & & \\
\hline Soil cover (flow) & & & & & & & & & & \\
\hline Crust Brokenness & & & & & & & & & & \\
\hline Cryptogram cover & & & & & & & & & & \\
\hline Erosion features & & & & & & & & & & \\
\hline Micro-topography & & & & & & & & & & \\
\hline
\end{tabular}




\section{Appendix 1 (cont'd)}

\section{Soil Surface Attribute Tables}

Soil Cover (rain): Interception of raindrops. Assesses the degree to which surface cover resists rainsplash erosion.

\begin{tabular}{|l|c|}
\hline Projected Cover & Class \\
\hline nil $(<1 \%)$ & 1 \\
\hline very low $(1-2 \%)$ & 2 \\
\hline low $(2-5 \%)$ & 3 \\
\hline moderate $(5-15 \%)$ & 4 \\
\hline high $(15-50 \%)$ & 5 \\
\hline very high $(>50 \%)$ & 6 \\
\hline
\end{tabular}

Crust Broken-ness: Assesses to what degree surface crust materials are broken, or loosely attached and available for erosion.

\begin{tabular}{|l|c|}
\hline Crust Broken-ness & Class \\
\hline extensively broken & 1 \\
\hline moderately broken & 2 \\
\hline slightly broken & 3 \\
\hline intact & 4 \\
\hline
\end{tabular}

Soil Cover (flow): Assesses the cover of features which obstruct or divert overland flow.

\begin{tabular}{|l|c|}
\hline Projected Cover & Class \\
\hline nil & 1 \\
\hline very low (2\%) & 2 \\
\hline low $(2-5 \%)$ & 3 \\
\hline moderate $(5-15 \%)$ & 4 \\
\hline high (15-50\%) & 5 \\
\hline very high ( $>50 \%)$ & 6 \\
\hline
\end{tabular}

\section{Cryptogam Cover: Assesses} the cover of cryptogams (algae, fungi, lichens, mosses, and liverworts).

\begin{tabular}{|l|c|}
\hline Cryptogam Cover & Class \\
\hline nil $(<1 \%)$ & 1 \\
\hline slight $(1-10 \%)$ & 2 \\
\hline moderate $(10-50 \%)$ & 3 \\
\hline extensive $(>50 \%)$ & 4 \\
\hline
\end{tabular}

Erosion Features: Assesses visible signs of active soil loss from the frame.

\begin{tabular}{|l|c|}
\hline Erosion Features & Class \\
\hline extensive & 1 \\
\hline moderate & 2 \\
\hline slight & 3 \\
\hline nil & 4 \\
\hline
\end{tabular}

Soil Microtopography: This is an assessment of soil surface "roughness" features which retain water.

\begin{tabular}{|l|c|}
\hline Surface water detention capacity & Class \\
\hline nil, smooth $(<3 \mathrm{~mm}$ deep $)$ & 1 \\
\hline slight, few shallow depressions $(3-8 \mathrm{~mm})$ & 2 \\
\hline moderate, deeper depressions $(8-15 \mathrm{~mm})$ & 3 \\
\hline high, deep, extensive $(15-25 \mathrm{~mm})$ & 4 \\
\hline very high, e.g. sink holes $(>25 \mathrm{~mm})$ & 5 \\
\hline
\end{tabular}




\section{Appendix 2}

\section{Line Intercept Data}

\begin{tabular}{|l|l|}
\hline Date: & Name of Investigator: \\
\hline Name of Location: & Transect Number \& GPS Coordinates (UTMs): \\
\hline
\end{tabular}

Transect Orientation:

Slope:

Aspect:

Habitat Type:

Dominant Plant Species:

General Comments (purpose of measurements, growing conditions, weeds, erosion, other disturbances, grazing level, etc.):

\begin{tabular}{|l|l|l|l|l|l|l|}
\hline $\begin{array}{l}\text { Transect } \\
\text { Number }\end{array}$ & Species & $\begin{array}{c}\text { Transect } \\
\text { Length }\end{array}$ & Start (cm & Stop (cm) & $\begin{array}{c}\text { Intercept } \\
(\mathrm{cm})\end{array}$ & $\begin{array}{c}\text { Height } \\
(\mathrm{cm})\end{array}$ \\
\hline & & & & & & \\
\hline & & & & & & \\
\hline & & & & & & \\
\hline & & & & & & \\
\hline & & & & & & \\
\hline & & & & & & \\
\hline & & & & & & \\
\hline & & & & & & \\
\hline & & & & & & \\
\hline & & & & & & \\
\hline & & & & & & \\
\hline & & & & & & \\
\hline
\end{tabular}




\section{Appendix 3}

\section{Photo Point Route Field Form}

Date:

Name of Photographer:

Name of Location: $\quad$ Date Photo Point Route was Established:

General Comments: (growing conditions, weeds, erosion, etc.)

\begin{tabular}{|l|l|l|l|l|l|l|}
\hline $\begin{array}{l}\text { Shoto Point } \\
\text { Number }\end{array}$ & $\begin{array}{c}\text { UTM } \\
\text { Zone }\end{array}$ & $\begin{array}{c}\text { UTM } \\
\mathrm{N}\end{array}$ & $\begin{array}{c}\text { UTM } \\
\mathrm{E}\end{array}$ & $\begin{array}{c}\text { Photo Point } \\
\text { Bearing }\end{array}$ & $\begin{array}{c}\text { Time of } \\
\text { Day }\end{array}$ & Comments \\
\hline & & & & & & \\
\hline & & & & & & \\
\hline & & & & & & \\
\hline & & & & & & \\
\hline & & & & & & \\
\hline & & & & & & \\
\hline & & & & & & \\
\hline & & & & & & \\
\hline & & & & & & \\
\hline & & & & & & \\
\hline & & & & & & \\
\hline & & & & & & \\
\hline & & & & & & \\
\hline & & & & & & \\
\hline & & & & & & \\
\hline & & & & & & \\
\hline & & & & & & \\
\hline & & & & & & \\
\hline & & & & & & \\
\hline
\end{tabular}




\title{
STATE DOCIIMENTS COLLECTION
}

\author{
APR 282006 \\ MONTANA STATE LIBRARY. \\ 1515 E. 6th AVE. \\ HELENA, MONTANA 59620
}




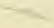


